\title{
Etika Profesi Guru Pendidikan Anak Usia Dini
}

\author{
1)ZHERLY NADIA WANDI, 2)NURHAFIZAH NURHAFIZAH \\ Program Studi Pendidikan Anak Usia Dini, Universitas Negeri Padang \\ Email: zherlynadia@gmail.com, nurhafizah.is.87@gmail.com
}

\begin{abstract}
This study aims to determine the professional ethics of early childhood education teachers in kindergartens in Padang Timur Subdistrict, Padang City. This study uses descriptive methods that are analytical. Respondents involved included teachers and principals. For the target population in this study were kindergarten teachers in Padang Timur District, Padang City in 5 Kindergarten Institutions with 41 samples. Data collection is done through observation or observation, interviews, and documentation. The results of the study indicate that in early childhood education teacher ethics, based on Republic of Indonesia Law Number 14 of 2005 concerning Teachers and Lecturers also Decision of the XXI Congress of the Republic of Indonesia Teacher Association Number: Vi / Congress / Xxi / Pgri / 2013 concerning Teacher Ethics Code Indonesia with its research focus, namely: The obligation of teachers to students; Obligations of teachers to parents or guardians of students; The obligation of teachers to colleagues indicates that teacher professional ethics are in accordance with those carried out in the field, but must be further optimized in its application.
\end{abstract}

Keywords: Teacher Professional Ethics, Early Childhood Education.

\begin{abstract}
Abstrak
Penelitian ini bertujuan untuk mengetahui etika profesi guru pendidikan anak usia dini di taman kanakkanak di Kecamatan Padang Timur, Kota Padang. Penelitian ini menggunakan metode deskriptif yang bersifat analitik. Responden yang terlibat termasuk guru, dan kepala sekolah. Untuk populasi target dalam penelitian ini adalah guru TK di Kabupaten Padang Timur, Kota Padang di 5 Lembaga TK dengan 41 sampel. Pengumpulan data dilakukan melalui observasi atau pengamatan, wawancara dan dokumentasi. Hasil penelitian menunjukkan bahwa dalam etika guru pendidikan anak usia dini, berdasarkan Undang-Undang Republik Indonesia Nomor 14 Tahun 2005 tentang Guru dan Dosen juga Keputusan Kongres XXI Republik Indonesia Asosiasi Guru No. Nomor: Vi / Kongres / Xxi / Pgri / 2013 tentang Kode Etik Guru Indonesia dengan fokus penelitiannya, yaitu: Kewajiban guru kepada siswa; Kewajiban guru kepada orang tua atau wali murid; Kewajiban guru kepada kolega menunjukkan bahwa etika profesi guru sesuai dengan yang dilakukan di lapangan, tetapi harus lebih dioptimalkan dalam penerapannya.
\end{abstract}

Kata Kunci: Etika Profesi Guru, Pendidikan Anak Usia Dini. 


\section{Pendahuluan}

Pendidikan hakikatnya adalah suatu usaha untuk memanusiakan manusia. Pendidikan merupakan salah satu kunci utama dalam membentuk sumber daya manusia yang berkualitas.(Saondi, ondi \& Aris Suherman, 2010). Pendidikan mencakup seluruh proses hidup dan bentuk interaksi manusia dengan lingkungannya dalam rangka untuk mengembangkan potensi yang sesuai dengan tahapan perkembangan secara optimal sehingga mencapai suatu taraf kedewasaan tertentu. Pendidikan merupakan proses untuk mengubah perilaku dan sikap seseorang maupun sekelompok orang dalam usaha mendewasakan manusia melalui upaya pembelajaran dan latihan (Susanna, 2014).

Penyelenggaran pendidikan merupakan suatu sistem yang diatur secara sistematis, sehingga pendidikan dapat berfungsi dalam mengembangkan kemampuan dan membentuk perilaku atau watak seseorang dan tujuannya untuk meningkatkan potensi peserta didik. (Saondi, ondi \& Aris Suherman, 2010)

Pendidikan anak usia dini tidak terlepas dari jasa seorang guru. Pendidikan bagi anak usia dini adalah berupa pemberian upaya yang dilakukan untuk membimbing, mengasuh, menstimulasi sehingga akan menghasilkan kemampuan dan keterampilan anak. Menurut Siswanto (2008:2), "Pendidikan anak memang harus dimulai sejak dini agar anak bisa mengembangkan potensinya secara optimal dengan tujuan agar anak-anak yang mengikuti PAUD menjadi lebih mandiri, disiplin, dan mudah diarahkan untuk menyerap ilmu pengetahuan secara optimal". Usia dini adalah anak yang berusi 0 sampai dengan 6 tahun, sedangkan usia TK adalah anak yang berusia 4 tahun sampai dengan 6 tahun. Batasan ini sesuai dengan batasan menurut Undangundang Nomor 20 Tahun 2003 Tentang Sistem Pendidikan Nasional yang menyatakan bahwa anak usia dii adalah sejak lahir sampai umur 6 tahun. Sesudah usia 6 tahun anak masuk sekolah dasar. (Suryana, 2011:31-32).

Pendidik sebagai penentu generasi muda harus dapat menjadi contoh atau tauladan karena di tangan pendidiklah generasi milenial ini akan menjadi generasi yang tangguh dan beriman yang siap melanjutkan estafet kepemimpinan yang lebih aman, damai, adil dan sejahtera (Ninoersy, 2015). Pendidik mengabdikan dirinya dan berbakti kepada negara untuk mencerdaskan kehidupan bangsa dan meningkatkan sumber daya manusia yang beriman, bertakwa, dan berakhlak mulia tetapi juga harus bisa mempelajari dan menguasai ilmu pengetahuan, teknologi, dan seni. Pendidik selalu tampil secara profesional dengan tugas utama mendidik, mengajar, membimbing, mengarahkan dan mengevaluasi (Gade, 2015).

Pendidik atau guru merupakan tenaga profesional, seorang guru harus bisa merencanakan pembelajaran, melaksanakan atau menerapkan proses pembelajaran, hasil proses pembelajaran, pembimbingan atau pelatihan dan melakukan pengabdian masyarakat.(Saondi, ondi \& Aris Suherman, 2010). Pendidik merupakan tenaga pengajar profesional yang merupakan unsur yang sangat penting dari proses pendidikan, sehingga pendidikan yang memenuhi etika adalah pendidikan yang memiliki akuntabilitas yang tinggi dalam penyelenggaraannya (Karwati, 2011). Jadi Pendidik yang profesional memiliki tanggung jawab dalam berbagai hal sesuai kebutuhan peserta didik dalam berbagai bidang, seperti bidang spiritual, intelektual, moral, etika, maupun fisik motorik peserta didik.

Guru yang mempunyai etika akan dapat mengatur hubungannya, baik antara guru dengan kepala sekolah, atau guru dengan sesama guru, guru dengan peserta didiknya dan guru dengan lingkungan. Penanaman perilaku disiplin kepada anak sejak usia dini sangat diperlukan yang merupakan bagian hubungan etika guru yang mengatur hubungan dengan peserta didiknya (Nurhafizah, 2014). Etika guru mengandung arti bahwa pekerjaan seorang guru berkaitan dalam merubah perilaku yang berkaitan dengan moral, norma dan penghormatan, sehingga guru dituntut untuk memiliki kemampuan dasar, yang diperlukan sebagai pendidik, pembimbing, dan pengajar. (Sutarsih, 2013). Jadi dapat disimpulkan bahwa etika guru akan menjunjung tinggi nilai-nilai profesionalisme dan mampu menanamkan perilaku yang baik kepada anak.

Profesional adalah seseorang yang ahli dalam pekerjaan atau kegiatan yang dilakukan oleh seseorang sesuai bidang keahlian, kemampuan atau keterampilan dan menjadi sumber penghasilan kehidupan yang memenuhi standar mutu atau norma 
tertentu serta memerlukan pendidikan profesi (Nurhafizah, 2011). Dahin (2002: 23) menyatakan bahwa, orang yang profesional memiliki sikap-sikap serta perilaku yang berbeda dengan orang yang tidak profesional meskipun orang tersebut berada dalam suatu pekerjaan yang sama.

Etika profesi guru berkaitan erat dengan kompetensi sesuai bidangnya yaitu baik secara keterampilan, pengetahuan maupun sikap dan perilaku. Menurut Mission (2001:18) bahwa competency is a combination of knowledge, skill, and attitude. Pernyataan tersebut memiliki makna bahwa kompetensi merupakan kombinasi antara pengetahuan, keterampilan dan sikap. Sedangkan Lynn dan Nixon (1985:33) menjelaskan competencies may range from recall and understanding of fact and concepts, to advanced motor skill, to teaching behaviors, and professional value. Artinya kompetensi terdiri dari pengalaman dan pemahaman tentang fakta dan konsep, peningkatan kehlian, pengajaran perilaku dan sikap. Jadi dapat disimpulkan bahwa kompetensi merupakan keahlian seseorang pada bidang tertentu, disini guru pendidikan anak usia dini yang diwujudkan melalui pengalaman, pengetahuan, sikap dan perilaku.

Etika menurut Ferrel (2013) adalah studi tentang sifat moral dan pilihan moral yang spesifik, filsafat moral, dan aturan-aturan atau standar yang mengatur perilaku para anggota profesi. Etika merupakan cabang ilmu filsafat berkaitan dengan konsep nilai-nilai yang baik dan menjadi panutan dalam hubungan kemanusiaan antar manusia seperti kebenaran, kebebasan, kejujuran, keadilan, cinta, kasih sayang yang terkait norma moralitas (Lubis, 2011). Etika adalah studi tentang standar moral dan pengaruhnya terhadap perilaku (Dutelle, 2011).

Etika kerja adalah seperangkat perilaku yang dimiliki oleh individu atau kelompok yang diimplementasikan dalam bekerja atau beraktivitas untuk mencapai tujuan yang telah ditetapkan dengan dilandasi nilai-nilai dan norma-norma yang dianut dengan indikator tepat waktu, jujur, memiliki motivasi untuk berkembang, bekerja keras, bertanggung jawab, kreatif, menghormati, menghargai dan komunikatif kepada peserta didik. (Sarjana, 2014). Sejalan dengan yang pendapat Nurhafizah (2011) dalam artikelnya bahwa berbagai peran multifungsi dengan etika dari seorang pendidik merupakan modal dasar yang sangat bermakna untuk membangun keterampilan komunikasi yang sangat efektif dalam pengendalian diri dan keberhasilan hubungan antara satu dengan yang lainnya. Jadi etika guru juga berkaitan erat dengan keterampilan komunikasi dalam hal pengendalian diri.

Etika atau filsafat moral yaitu mengacu pada kehidupan yang baik, tentang apa yang baik dan buruk, tentang apakah ada tujuan yang benar dan salah, dan bagaimana mengetahui hal itu ada (Mackinnon, 2013). Dalam kode etik guru disebutkan bahwa guru memelihara hubungan seprofesi, semangat kekeluargaan, dan kesetiakawanan sosial. Hal ini berarti bahwa guru hendaknya menciptakan dan memelihara hubungan sesama guru dalam lingkungan kerja. Selain itu, guru hendaknya menciptakan dan memelihara semangat kekeluargaan dan kesetiakawanan sosial baik di dalam maupun di luar lingkungan kerja (Sarjana, 2014).

Dalam masyarakat Indonesia, guru memegang peranan strategis terutama dalam upaya membentuk watak bangsa melalui pengembangan kepribadian dan nilai-nilai yang diinginkan. Peranan guru masih dominan meskipun teknologi yang dapat dimanfaatkan dalam proses pembelajaran berkembang amat cepat. Hal ini dikarenakan ada dimensi-dimensi atau perantara dari proses pendidikan, atau lebih khusus lagi proses pembelajaran, yang diperankan oleh guru yang tidak dapat digantikan oleh teknologi.

Fungsi guru tidak akan bisa seluruhnya dihilangkan sebagai pendidik dan pengajar bagi peserta didiknya. Sehubungan dengan hal itu, tenaga pendidik haruslah disiapkan untuk memenuhi layanan interaksi dengan peserta didik. Hal ini sebagaimana diamanatkan oleh UU No. 14 tahun 2005 tentang Guru dan Dosen pasal 1 ayat (1) "Guru adalah pendidik profesional dengan tugas utama mendidik, mengajar, membimbing, mengarahkan, melatih, menilai, dan mengevaluasi peserta didik pada pendidikan anak usia dini jalur pendidikan formal, pendidikan dasar, dan pendidikan menengah". Profesionalisme dalam pendidikan perlu dimaknai bahwa guru haruslah orang yang memiliki insting sebagai pendidik, mengerti dan memahami peserta 
didik. Jadi dapat disimpulkan guru harus mampu untuk menguasai dan mendalami minimal satu bidang keilmuan atau guru harus ahli dibidang yang dipilinnya dan harus memiliki sikap integritas professional kemudian mampu mengembangkan seluruh potensi dan kecedasan anak.

Selain rangsangan pendidikan yang mengembang seluruh aspek perkembangan anak juga harus dapat menanamkan dan menumbuhkan pembinaan perilaku dan sikap yang dilakukan melalui pembiasaan yang baik. Oleh sebab itu melihat pentingnya pendidikan anak usia dini, seorang guru harus mempunyai etika yang baik agar dapat menjadikan anak bermoral dan mematuhi mornanorma yang berlaku.

Berdasarkan Undang-undang Republik Indonesia No. 14 tahun 2005 Pasal 20 (a) menyatakan bahwa dalam melaksanakan tugas keprofesionalan, guru berkewajiban : Menjunjung tinggi peraturan perundang-undangan, hukum, dan kode etik guru, serta nilai-nilai agama dan etika. Sedangkan pada Pasal 43 (1) Untuk menjaga dan meningkatkan kehormatan dan martabat guru dalam pelaksanaan tugas keprofesionalan, organisasi profesi guru membentuk kode etik. (2) Kode etik sebagaimana dimaksud pada ayat (1) berisi norma dan etika yang mengikat perilaku guru dalam pelaksanaan tugas keprofesionalan. Melalui organisasi profesi, Kode Etik Guru dapat dilahirkan dan diterapkan, sehingga dapat mengontrol dan menjaga perilaku guru. Tahun 2008 untuk mempertegas penjaminan keprofesionalitasan guru, Persatuan Guru Republik Indonesia (PGRI) sebagai organisasi profesi guru mengembangkan Kode Etik Guru. Jadi dapat disimpulkan bahwa undang-undang republik indonesia nomor 14 tahun 2005 sudah menjelaskan bahwa dalam guru yang profesional berkewajiban untuk menjunjung tinggi nilai-nilai etika dan mengikat perilaku guru yang bertujuan untuk menjaga dan meningkatkan kehormatan dan marabat guru itu sendiri dalam bertingkah laku.

Berdasarkan pengamatan yang dilakukan peneliti di beberapa TK di Kecamatan Padang Timur Kota Padang, ada beberapa permasalahan yang sering kali terjadi dalam Pendidikan Anak Usia Dini mengenai etika guru, diantaranya 1) Ketika terjadi pertengkaran antara anak dengan anak lainnya, sebagai guru apa yang harusnya dilakukan; 2) Seorang guru yang membicarakan kejelekkan guru lainnya; 3) Bagaimana sikap seorang guru ketika masih ada anak yang belum dijemput orang tuanya; Berdasarkan pemaparan permasalahan diatas dapat dirumuskan masalahnya yaitu bagaimana etika guru pendidikan anak usia dini berdasarkan Undangundang Republik Indonesia Nomor 14 Tahun 2005 Tentang Guru dan Dosen.

\section{Tujuan Penelitian}

Penelitian ini bertujuan untuk mengetahui etika profesi guru pendidikan anak usia dini di Kecamatan Padang Timur Kota Padang, untuk mengetahui perbedaan serta gambaran keadaan yang sebenarnya etika profesi guru yang didasarkan Undang-undang Republik Indonesia Nomor No 14 tahun 2005 tentang Guru dan Dosen dan Keputusan Kongres XXI Persatuan Guru Republik Indonesia Nomor : Vi /Kongres/Xxi/Pgri/2013 tentang Kode Etik Guru Indonesia.

\section{Tinjauan Pustaka \\ Etika}

Etika didefinisikan sebagai " $A$ set of rules that define right and wrong conducts" (William C. Frederick, 1998:52). Maksud dari pengertian tersebut adalah Seperangkat peraturan/undang-undang yang ditetapkan untuk menentukan mana perilaku benar dan mana yang salah. Etika merupakan suatu studi moralitas. Kita dapat mendefinisikan moralitas sebagai pedoman atau standar bagi individu atau masyarakat tentang tindakan benar dan salah atau baik dan buruk. Dengan perkataan lain bahwa moralitas merupakan standar atau pedoman bagi individu atau kelompok dalam menjalankan aktivitasnya (Sutarsih, 2012).

\section{Etika profesi}

Etika profesi keguruan merupakan bagian dari etika umum yang mengatur perilaku seorang guru. Norma moralitas merupakan dasar atau pondasi yang menjadi acuan profesi dalam berperilaku yang baik dan benar. Dasar perilakunya tidak hanya hukumhukum pendidikan dan prosedur kependidikan saja yang mendorong perilaku guru itu, tetapi nilai moral dan etika juga menjadi acuan penting yang harus 
dijadikan landasan kebijakannya (Sutarsih, 2012). Jadi Etika profesi guru berkaitan erat dengan kompetensi sesuai bidangnya yaitu baik secara keterampilan, pengetahuan maupun sikap dan perilaku.

\section{Undang-undang Republik Indonesia Nomor 14 tahun 2005 tentang Guru dan Dosen}

Berdasarkan Undang-undang Republik Indonesia No. 14 tahun 2005 Pasal 20 (a) menyatakan bahwa dalam melaksanakan tugas keprofesionalan, guru berkewajiban : Menjunjung tinggi peraturan perundang-undangan, hukum, dan kode etik guru, serta nilai-nilai agama dan etika. Sedangkan pada Pasal 43 (1) Untuk menjaga dan meningkatkan kehormatan dan martabat guru dalam pelaksanaan tugas keprofesionalan, organisasi profesi guru membentuk kode etik. (2) Kode etik sebagaimana dimaksud pada ayat (1) berisi norma dan etika yang mengikat perilaku guru dalam pelaksanaan tugas keprofesionalan. Jadi didalam undang-undang ini telah dijelaskan tentang etika guru seperti apa dan dikembangkan menjadi kode etik guru.

\section{Keputusan Kongres XXI Persatuan Guru Republik Indonesia Nomor : Vi /Kongres/Xxi/Pgri/2013 tentang Kode Etik Guru Indonesia}

Kode Etik Guru dapat dilahirkan dan diterapkan, sehingga dapat mengontrol dan menjaga perilaku guru. Untuk mempertegas penjaminan keprofesionalitasan guru, Persatuan Guru Republik Indonesia (PGRI) sebagai organisasi profesi guru mengembangkan Kode Etik Guru. Jadi dapat disimpulkan bahwa undang-undang republik indonesia nomor 14 tahun 2005 sudah menjelaskan bahwa dalam guru yang profesional berkewajiban untuk menjunjung tinggi nilai-nilai etika dan mengikat perilaku guru yang bertujuan untuk menjaga dan meningkatkan kehormatan dan marabat guru itu sendiri dalam bertingkah laku.

\section{Penelitian Terdahulu}

Loannis, Raptis \& Eirini Spanaki (2017) dengan judul 'Teachers' Attitudes Regarding the Development of Socio -Emotional Skills in Elementary Schools in Greece", tentang Sikap Guru Mengenai
Pengembangan Keterampilan Sosial-Emosional di Sekolah Dasar, yang mana tujuan dari penelitiannya adalah untuk menyelidiki sikap guru. Persamaan penelitian yang dilakukan yaitu meneliti mengenai sikap atau etika guru. Bedanya, penelitian yang dilakukan peneliti dilaksanakan di Taman Kanakkanak berupa analisis deskriptif, sedangkan penelitian ini di laksanakan di sekolah dasar berupa studi kualitatif dan studi kasus dengan menerapkan metodologi pendekatan penelitian tindakan pendidikan.

\section{Metodologi Penelitian}

Tujuan utama penelitian ini adalah untuk menganalisis etika guru pendidikan anak usia dini di TK se Kecamatan Padang Timur Kota Padang. Penelitian ini menggunakan pendekatan deskriptif. Menurut Sukardi (2016:157) bahwa penelitian deskriptif dilakukan dengan tujuan utama yaitu menggambarkan atau mendeskripsikan secara sistematis fakta dan karakteristik objek atau subjek yang diteliti, penelitian deskriptif juga berguna untuk mendapatkan berbagai macam permasalahan atau persoalan yang berkaitan dengan bidang pendidikan maupun tingkah laku manusia. Pendekatan deskriptif dalam penelitian ini bersifat analisis. Bersifat analisis karena tujuan penelitian ini adalah untuk mengetahui perbedaan atau mengumpul data sesuai keadaan lingkungan yaitu antara kondisi yang seharusnya atau diharapkan dengan kondisi yang ada. Kondisi yang yang seharusnya disebut dengan kondisi ideal, sedangkan kondisi yang ada, disebut dengan kondisi riil atau kondisi nyata. Deskriptif ditujukan untuk mendapatkan gambaran suatu keadaan yang sebenarnya.

Responden yang terlibat meliputi guru, dan kepala sekolah. Untuk populasi sasaran dalam penelitian ini adalah guru-guru Taman Kanak-kanak di Kecamatan Padang Timur, Kota Padang yaitu 5 Lembaga Taman Kanak-kanak berjumlah 41 sampel. Pengumpulan data dilakukan melalui observasi atau pengamatan, wawancara dan dokumentasi. Observasi merupakan teknik pengumpulan data berupa pengamatan langsung ke lapangan. Wawancara merupakan teknik pengumpulan data berupa pertanyaan-pertanyaan yang terkait masalah yang akan di bahas. Sedangkan dokumentasi adalah 
Teknik pengumpulan data berupa arsip dokumen atau data gambar. Instrumen lain yang digunakan adalah dokumen yang berhubungan dengan topik berupa pustaka/kajian perpustakaan. Peneliti melakukan observasi berdasarkan kode etik guru berdasarkan pada undang-undang republik Indonedia Nomor 14 tahun 2005 dan Keputusan Kongres XXI Persatuan Guru Republik Indonesia Nomor : Vi /Kongres/Xxi/Pgri/2013 tentang Kode Etik Guru Indonesia dengan permasalahan yang dihadapi subjek.

\section{Hasil dan Pembahasan}

Hasil penelitian menemukan bahwa etika profesi guru diwujudkan melalui pengalaman, pengetahuan, sikap dan perilaku berdasarkan undang-undang republik indonesia nomor 14 tahun 2005 tentang guru dan dosen pada pasal 43 (1) Untuk menjaga dan meningkatkan kehormatan dan martabat guru dalam pelaksanaan tugas keprofesionalan, organisasi profesi guru membentuk kode etik Etika profesi guru dilakukan melalui organisasi profesi yaitu adanya Kode Etik Guru sebagai pedoman perilaku guru dalam melaksanakan tugas keprofesionalannya. Kode etik dilahirkan dan diterapkan, sehingga dapat mengontrol dan menjaga perilaku guru. Tahun 2008 untuk mempertegas penjaminan keprofesionalitasan guru, Persatuan Guru Republik Indonesia (PGRI) sebagai organisasi profesi guru mengembangkan Kode Etik Guru.

Etika profesi sebagai kontrol atas keahlian atau guru yang ahli dibidangnya. Guru merupakan tenaga pendidik, dinyatakan sebagai tenaga profesional berdasarkan Undang-undang Republik Indonesia Nomor 14 tahun 2005 tentang Guru dan Dosen, sehingga guru juga terikat dengan etika profesinya.

Etika profesi yang berlaku bagi guru disusun dan dikembangkan oleh organisasi profesi guru yaitu PGRI. Kode etik yang disusun oleh PGRI ini bertujuan untuk menjadikan guru sebagai pendidik yang handal dan mampu mengembangkan seluruh potensi peserta didik.

Berapa persoalan yang terkait etika profesi guru, yang menjadi fokus dalam penelitian ini yang didasarkan pada Keputusan Kongres XXI Persatuan Guru Republik Indonesia Nomor : Vi
/Kongres/Xxi/Pgri/2013 tentang Kode Etik Guru Indonesia, yaitu :

1) Kewajiban guru terhadap peserta didik

2) Kewajiban guru terhadap orangtua atau wali murid

3) Kewajiban guru terhadap teman sejawat

Berdasarkan pasal 2 Kode Etik Guru yang disusun oleh PGRI mengenai kewajiban guru terhadap peserta didik, menyebutkan bahwa :

1) Bertindak profesional dalam melaksanakan tugas mendidik, mengajar, membimbing, mengarahkan, melatih, menilai, dan mengevaluasi proses dan hasil belajar peserta didik.

2) Memberikan layanan pembelajaran berdasarkan karakteristik individual serta tahapan tumbuh kembang kejiwaan peserta didik.

3) Mengembangkan suasana pembelajaran yang aktif, kreatif, efektif dan menyenangkan.

4) Menghormati martabat dan hak-hak serta memperlakukan peserta didik secara adil dan objektif.

5) Melindungi peserta didik dari segala tindakan yang dapat mengganggu perkembangan, proses belajar, kesehatan, dan keamanan bagi peserta didik.

6) Menjaga kerahasiaan pribadi peserta didik, kecuali dengan alasan yang dibenarkan berdasarkan hukum, kepentingan pendidikan, kesehatan, dan kemanusiaan.

7) Menjaga hubungan profesional dengan peserta didik dan tidak memanfaatkan untuk keuntungan pribadi dan/atau kelompok dan tidak melanggar norma yang berlaku.

Bunyi Pasal 2 Kode Etik Guru ini dapat digunakan sebagai panduan bagi guru untuk bersikap dan berperilaku terhadap peserta didiknya. Berdasarkan wawancara dengan beberapa guru dapat di simpulkan bahwa : 1) Guru sudah bisa mengendalikan dan memberi contoh yang baik kepada anak didik ketika terjadi pertengkaran antara anak satu dengan lainnya, tetapi tidak perlu menyudut anak yang bersalah; 2) Guru sudah bisa mengembangkan suasana belajar yang menarik dan menyenangkan, karena guru-guru disini sering melaksanakan kegiatan KKG (Kelompok Kerja Guru) 
yang tujuan kegiatan dari forum ini untuk meningkatkan kreativitas guru; 3) Guru masih belum optimal dalam memberikan layanan keamanan bagi peserta didik, contohnya dari beberapa guru yang diwawancarai yaitu kurangnya pengawasan kurang ketika anak bermain di area luar ruangan. Seharusnya kalau berdasarkan kode etik guru, seorang guru harus bisa melindungi peserta didiknya, temasuk pengawasan dalam bermain. Secara umum Kewajiban guru terhadap peserta didik yang didasarkan UU RI Nomor 14 tahun 2005 dan Keputusan Kongres XXI Persatuan Guru Republik Indonesia Nomor : Vi /Kongres/Xxi/Pgri/2013 sudah dilaksanakan sesuai keputusan tetapi ada beberapa hal yang belum optimal dilakukan

\section{Kewajiban guru terhadap orangtua atau wali murid}

1) Menghormati hak orang tua/wali peserta didik untuk berkonsultasi dan memberikan informasi secara jujur dan objektif mengenai kondisi dan perkembangan belajar peserta didik.

2) Membina hubungan kerja sama dengan orang tua/wali peserta didik dalam melaksanakan proses pendidikan untuk peningkatan mutu pendidikan.

3) Menjaga hubungan profesional dengan orang tua/wali peserta didik dan tidak memanfaatkan untuk memperoleh keuntungan pribadi.

Berdasarkan bunyi Pasal 3 Kode Etik Guru yang menuntut guru harus menghormati hak orang tua/wali peserta didik, harus bisa membina hubungan yang baik dengan orangtua/ wali peserta didik dan menjaga hubungan agar tetap harmonis dengan orangtua/wali peserta didik. Berdasarkan hasil wawancara dengan beberapa guru di Kecamatan Padang Timur, mengatakan : Guru senantiasa memberi kesempatan pada orangtua untuk bertanya mengenai perkembangan anaknya; Ketika ada orang tua yang terlambat menjemput anaknya, Guru menanyakan alasan ketika orangtua terlambat menjemput anak, dan memberi tahu jam pulang agar dijemput tepat waktu; Ada beberapa orangtua yang suka marah ketika anaknya terjatuh disekolah, tanpa mengetahui sebab dan kenapanya, disini sikap seorang harus bisa mengontrol emosinya dan menjelaskan baik-baik kepada orangtua/wali peserta didik.

Jadi Kewajiban guru terhadap orang tua/wali murid peserta didik yang didasarkan UU RI Nomor 14 tahun 2005 dan Keputusan Kongres XXI Persatuan Guru Republik Indonesia Nomor Vi /Kongres/Xxi/Pgri/2013 belum berjalan dengan optimal, harusnya guru dan orangtua murid bekerjasama dalam memberikan layanan pendidikan kepada anak.

\section{Kewajiban guru terhadap teman sejawat}

1) Membangun suasana kekeluargaan, solidaritas, dan saling menghormati antarteman sejawat di dalam maupun di luar satuan pendidikan.

2) Saling berbagi ilmu pengetahuan, teknologi, seni, keterampilan, dan pengalaman, serta saling memotivasi untuk meningkatkan profesionalitas dan martabat guru.

3) Menjaga kehormatan dan rahasia pribadi teman sejawat.

4) Menghindari tindakan yang berpotensi menciptakan konflik antarteman sejawat.

Berdasarkan bunyi Pasal 5 Kode Etik Guru, guru harus bisa menciptakan suasana kekeluargaan di sekolah, saling berbagi ilmu, menjaga rahasia teman sejawat, dan harus bisa menghindari pertengkaran dengan teman sejawat. Berdasarkan hasil wawancara dengan beberapa orang gurudan kepala sekolah : mengatakan bahwa guru-guru sudah memelihara hubungan baik dengan teman sejawatnya, tetapi yang menjadi permasalahan yaitu seringnya berbeda pendapat atau salah penafsiran tentang suatu hal, sehingga ada kecekcokan. Adapun upaya yang dilakukan oleh kepala sekolah ketika guru-guru mengalami konfik yaitu melakukan kunjungan pribadi terhadap guru yang bermasalah tadi, setelah mendengar dari berbagai sisi barulah kepala sekolah mengadakan forum diskusi atau rapat sederhana untuk menyelesaikan masalah guru yang bersangkutan.

Berdasarkan hasil diatas dijelaskan bahwa : (1) Dalam meningkatkan etika guru pendidikan anak usia dini, sudah diadakan KKKP (Kelompok Kerja Kepala PAUD) dan KKG (Kelompok Kerja Guru), Suatu organisasi yang mewadahi untuk meningkatkan keprofesionalan guru salah satunya etika guru 
pendidikan anak usia dini. Karena menurut Undangundang Republik Indonesia Nomor 14 Tahun Tentang Guru dan Dosen, pemaparan mengenai etika guru dijabarkan pada Pasal 43 (1) Untuk menjaga dan meningkatkan kehormatan dan martabat guru dalam pelaksanaan tugas keprofesionalan, organisasi profesi guru membentuk kode etik. (2) Kode etik sebagaimana dimaksud pada ayat (1) berisi norma dan etika yang mengikat perilaku guru dalam pelaksanaan tugas keprofesionalan. Dipertegas dengan Keputusan Kongres XXI Persatuan Guru Republik Indonesia Nomor Vi /Kongres/Xxi/Pgri/2013 tentang Kode Etik Guru Indonesia, Jadi dapat disimpulkan bahwa analisis etika guru pendidikan anak usia dini di Kecamatan Padang Timur Kota Padang, sudah sesuai dengan keputusan atau kebijakan yang ditetapkan, walaupun ada beberapa poin ketika dilaksanakan dilapangan tidak berjalan dengan optimal. Jadi diperlukan lagi kerjasama guru dan kepala sekolah serta orangtua/wali murid dalam memberikan layanan pendidikan pada anak sehingga dengan begitu guru juga dapat meningkatkan kompetensi serta etika atau perilaku yang baik dalam pembelajarannya.

\section{Kesimpulan}

Pembahasan di atas menunjukkan bahwa analisis etika guru pendidikan anak usia dini di Kecamatan Padang Timur Kota Padang, menunjukkan memang ada perbedaan yang terjadi dilapangan. Tetapi dari analisis juga terlihat dibeberapa TK ini untuk etika guru sudah berdasarkan Undang-undang Nomor 14 Tahun 2005 Tentang Guru dan Dosen juga dipertegas dengan Keputusan Kongres XXI Persatuan Guru Republik Indonesia Nomor Vi /Kongres/Xxi/Pgri/2013 tentang Kode Etik Guru Indonesia yang mana etika profesi guru pendidikan anak usia dini di Kecamatan Padang Timur ini sudah dilaksanakan walaupun belum optimal dalam penerapannya.

\section{Daftar Pustaka}

Dahin, S. 2002. Inovasi pendidikan dalam upaya peningkatan profesionalisme tenaga pendidikan. Bandung: Pustaka Setia.

Dutelle, A. W. 2011. Ethics For The Public Service Professional. Boca Raton: CRC Press.
Ferrell, O. C. 2013. Business Ethics: Ethical Decision Making and Cases, 9th Edition. South Western: Cengage Learning.

Gade, S. 2015. Kode Etik Pendidik Menurut Ibnu Jama'ah. Jurnal Pencerahan, 9(1), 23-36

loannis, Raptis \& Eirini Spanaki. 2017. Teachers' Attitudes Regarding the Development of Socio -Emotional Skills in Elementary Schools in Greece. International Journal of Psychology and Educational Studies, 2017, 4 (1), 21-28

Karwati, E. 2011. Etika Pengelolaan Pendidikan Untuk Menjamin Kualitas dan Profesionalisme. Bandung: Alfabeta.

Keputusan Kongres XXI Persatuan Guru Republik Indonesia Nomor Vi /Kongres/Xxi/Pgri/2013 tentang Kode Etik Guru Indonesia

Lubis, D. 2011. Etika Pendidikan dan Pengembangan Sumber Daya Manusia. Bandung: Alfabeta.

Lynn, V. C., \& Nixon, J. E. 1985. Physical education: teacher education, guidliness for sport pedagogy. New York: Jhon Wiley \& Sons. Inc.

MacKinnon, B. 2013. Ethics: Theory \& Contemporary Issues - Concise, 2nd Edition. Boston: Cengage Learning.

Mission, D. A. 2001. Training manual on competency based learning assesment. AGAMI Printing \& Publishing Co.

Ninoersy, T. 2015. Integritas Pendidik Profesional dalam Tinjauan Al-Qur'an. Jurnal Edukasi, 1(2), 113-135.

Nurhafizah. 2011. Kemampuan Berkomunikasi Sebagai Pilar Profesionalisme Guru Dalam Membimbing Anak Usia Dini. Artikel Proseding. Bandung : FIP UPI.

Nurhafizah.2014. Penanaman Perilaku Disiplin Pada Anak Sejak Usia Dini. Konferensi Seminar Nasional Trend Pendidikan Anak Usia Dini Dimasa Depan Jilid1. PG-PAUD FIP UNP.

Saondi, Ondi \& Arif Suherman. 2010. Etika Profesi Keguruan. Bandung : PT Refika Aditama.

Sarjana, S. 2014. Pengaruh Kepemimpinan dan Kerjasama Tim Terhadap Etika Kerja Guru. Jurnal Pendidikan dan Kebudayaan, 20(2), 234-250.

Siswanto, Igrea. 2008. Mendidik Anak Dengan Permainan Kreatif. Yogyakarta: ANDI. 
Sukardi. 2016. Metodologi Penelitian Pendidikan. Jakarta : Bumi Aksara.

Suryana. Dadan. 2011. Pembentukan Karakter Anak Usia Dini Berbasis Universalitas Nilai Indonesia. Prosiding Seminar Nasional Pendidikan Karakter Sejak Usia Dini ISBN 978 UNP \& UNRAM

Susanna. 2014. Kepribadian Guru PAI dan Tantangan Globalisasi. Jurnal Mudarrisuna, 4(2), 376-396.

Sutarsih, Cicih. 2013. Etika Profesi. Jakarta : Direktorat Jenderal Pendidikan Islam Kementerian Agama RI.

Undang-undang Nomor 14 Tahun 2005 tentang Guru dan Dosen

William C. Frederick; Keith Davis; James E. Post,. 1988. Business and Society, Corporate Strategy, Public Policy, Ethics, Mc Graw-Hill, Publishing Company. 